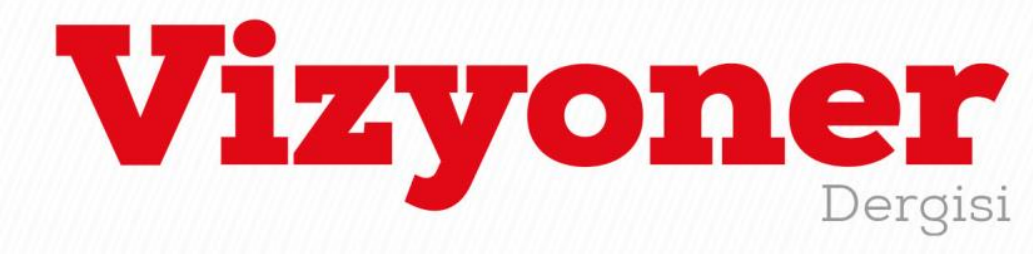

Süleyman Demirel Üniversitesi Vizyoner Dergisi, Yıl: 2021, Cilt: 12, Sayı: 29, 224-234.

Süleyman Demirel University Visionary Journal, Year: 2021, Volume: 12, No: 29, 224-234.

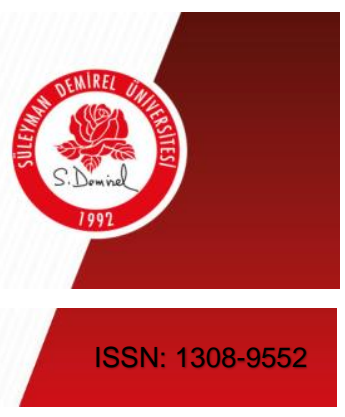

ARAŞTIRMA MAKALESİ / RESEARCH ARTICLE

HEALTH SEEKING BEHAVIOR: SCALE DEVELOPMENT STUDY*

SAĞLIK ARAMA DAVRANIŞI: ÖLÇEK GELIŞTİRME ÇALIŞMASI

\author{
Res. Asst. Dr. Ramazan KIRAÇ ${ }^{1}$ \\ Assoc. Prof. Dr. Yunus Emre ÖZTÜRK²
}

\begin{abstract}
The aim of the study is to develop a measurement tool to determine the health-seeking behavior of individuals. The study is applied on 401 people aged 18 and older residing in Selçuklu district of Konya. Literature reviews, expert advice and results of individual interviews, a 30-item question pool is created. Exploratory factor analysis (AFA) and confirmatory factor analysis (CFA) are performed with the data obtained from the pilot application. As a result of AFA, a 3-factor 16-item structure is obtained. The Kaiser-Meyer Olkin (KMO) coefficient is 0.810 and the Barlett test is significant ( $\mathrm{p}<0.001$ ). However, as a result of the subsequent CFA analysis, the $t$ values of 4 items are lower than 1.96. These items are excluded because they adversely affect the goodness of fit index values. As a result of the removal of these substances, DFA analysis is performed. As a result of the research, a scale consisting of 12 items and 3 factors showing health seeking behavior for individuals is developed. Online search behavior consists of 6 items, professional search behavior 3 items, and traditional search behavior 3 items.
\end{abstract}

Keywords: Health Seeking Behavior, Online Search, Traditional Search, Professional Search.

JEL Classification Codes: I10, I12, I19.

ÖZ

Bu çalışmanın amacı, bireylerin sağlık arama davranışını belirlemek için bir ölçüm aracı geliştirmektir. Araştırma Konya'nın Selçuklu ilçesinde ikamet eden 18 yaş ve üzeri 401 kişiye uygulanmıştır. Literatür taramaları, bireylerle görüşmeler ve uzman önerileri sonucu 30 maddelik soru havuzu oluşturulmuştur. Uygulama sonucu elde edilen verilerle açımlayıcı faktör analizi (AFA) ve doğrulayıcı faktör analiz (DFA) sırasıyla yapılmıştır. AFA sonucu 3 faktörlü 16 maddelik yapı elde edilmiştir. KaiserMeyer Olkin (KMO) katsayısının 0,810 ve Barlett testinin ise anlamlı olduğu $(\mathrm{p}<0.001)$ görülmüştür. Ancak daha sonra yapılan DFA analizi sonu 4 maddenin daha t değerlerinin 1.96 altında çıkmıştır. Bu maddeler uyum iyiliği indeks değerlerini olumsuz etkilediği için çıkarılmıştır. Bu maddelerin çıkarılması sonucu tekrardan DFA analizi yapılmıştır. Araştırma sonucunda, bireyler için sağlık arama davranışını gösteren 12 madde ve 3 faktörden oluşan bir ölçek geliştirilmiştir. Online arama davranışı 6 madde, profesyonel arama davranışı 3 madde ve geleneksel arama davranışı 3 maddeden oluşmaktadır.

Anahtar Kelimeler: Sağlık Arama Davranışı, Online Arama, Geleneksel Arama, Profesyonel Arama.

JEL Sinıflandırma Kodları: I10, I12, I19.

* The study is prepared from the Ph. D. dissertation of Ramazan KIRAÇ titled "Factors Affecting the Health Seeking Behavior: A Study Based on Structural Equation Modeling" whose supervisor is Assoc. Prof. Yunus Emre ÖZTÜRK and that is supported defended on 14.11.2019. For the study, ethics committee approval no 2018/122 dated 25.04.2018 is taken from the Ethics Committee of Selcuk University Faculty of Health Sciences.

1 (D) Kahramanmaraş Sütçü İmam University, Faculty of Economics and Administrative Sciences, Department of Health Management, ramazan46k@gmail.com

2 (D) Selcuk University, Faculty of Health Sciences, Department of Health Management, yunuseozturk@gmail.com

$\begin{array}{lll}\text { Makale Geliş Tarihi / Received } & : 18.06 .2020 & \text { DOI: 10.21076/vizyoner.754526 } \\ \text { Makale Kabul Tarihi / Accepted } & : 08.01 .2021 & \end{array}$




\section{GENIŞLETILMIŞ ÖZET}

\section{Amaç ve Kapsam:}

Sağlığı ile ilgili şikâyetleri olan bireyler, hemen her kültürde bu şikâyetleri gidermek için çeşitli arayışlar içerisine girmektedir. Sadece kendi sağlığı için değil yakınlarının sağlı̆̆ı içinde bu arayışları devam ettirmektedir. Bu arayış, bazen bir hekime başvuru, bazen kendi kendine ilaç kullanma, bazen güvendiği bir kişinin önerisine uyma, bazen doğaüstü güçlerden yardım umma, bazen de internetten bilgi arama gibi uygulamalarla sonuçlanmaktadır. Bu çalışmanın amacı, bireylerin sağlık arama davranışını belirlemek için bir ölçüm aracı geliştirmektir.

\section{Yöntem:}

Araştırma Konya'nın Selçuklu ilçesinde ikamet eden 18 yaş ve üzeri kişilere uygulanmıştır. Araştırmanın evreni 449.749 kişiden oluşmakta olup, kolayda örneklem yöntemi kullanılarak 401 kişiye ulaşılmıştır. Araştırmalar, verilerin toplanma zamanına göre anlık, kesitsel ve boylamsal olmak üzere üçe ayrılırlar. Buna göre araştırma için ihtiyaç duyulan veriler belirlenen bir aralıkta anlık olarak araştırmacı tarafından, anket tekniği kullanılarak toplandı. Ankette ilk olarak bilgilendirilmiş onam bulunmaktadır, daha sonra demografik veriler ve ölçek yer almaktadır. Çalışmada elde edilen bulgular değerlendirilirken SPSS (Statistical Package for Social Sciences) ve LISREL programı kullanılmıştır.

\section{Bulgular:}

Katılımcıların \%46,1'i kadın \%53,9'u erkektir. Araştırmaya katılanların \%80,8'inde kronik bir rahatsızlık bulunmamaktadır. Sağlık arama davranışı ölçeğinin geliştirilmesinde ilk olarak kapsam geçerliliği daha sonra ise yapı geçerliliği yapılmıştır. Ölçeğin kapsam geçerliliği için ilgili literatür taranmış ve uzman görüşlere de başvurularak ölçek toplam 30 maddeden oluşmuştur. Katılımcılardan, "Tamamen katılıyorum", "Katılıyorum”,"Kısmen Katılıyorum", "Katılmıyorum” ve "Kesinlikle katılmıyorum" arasında değişen 5'li Likert tipi bir ölçek üzerinde kendi algılarını ifade etmeleri beklenmiştir. Her madde için "Tamamen katıliyorum 5 puan, katılıyorum 4 puan, karasızım 3 puan, katılmıyorum 2 puan ve kesinlikle katılmiyorum 1 puan" şeklinde değerlendirilmiştir. Ölçeğin faktör yapısını ortaya koymak amacıyla açımlayıcı faktör analizi yapılmıștır. Faktör analizi öncesinde, verilerin ve örneklemin temel bileşenler analizine uygunluğunun incelenmesi amacıyla yapılan KaiserMeyer Olkin (KMO) ve Barlett testleri sonucunda, Kaiser-Meyer Olkin (KMO) katsayısının 0.810 ve Barlett testinin ise anlamlı olduğu $(\mathrm{p}<0.001)$ görülmüştür. KMO katsayısının 0.60 değerinin üzerinde olması ve Bartlett testinin anlamlı bulunması $(\mathrm{p}<0.001)$, veri setinin temel bileşenler analizi için uygunluğunu, faktörleştirilebilirliğini ve örneklem büyüklügünün $(n=401)$ yeterli olduğunu göstermektedir. Gerçekleştirilen faktör analizi sonrasında elde edilen değerler incelenirken; ölçek maddelerinin tek bir faktörde yüksek yük değerine sahip olmasına ve iki veya daha fazla faktördeki yük değerleri farkının en az 0.1 ve yer aldıkları faktördeki yük değerlerinin 0.45 veya bu değerden daha yüksek olmasına dikkat edilmiştir. Çok faktörlü bir ölçekte birden çok faktörde yüksek yük değerine sahip maddeler ölçekten çıkartılması gerektiği için, iki faktörde yüksek yük değerine ( 0.45 değerinin üstünde) sahip on dört madde ölçekten çıkartılmıştır. Geriye kalan 16 madde ile yeniden analiz yapılmıştır. Açımlayıcı faktör analizi ile sağlık arama davranışı ölçeğine ilişkin temel faktörler belirlenmiş olmakla birlikte, belirlenen faktörlerin kalitesine, ölçeğin genel yapısına ve ilgili ölçeğin sağlık arama davranışını ne derece açıkladığına yönelik bilgiler doğrulayıcı faktör analizi yapılmak suretiyle tespit edilmiştir. Doğrulayıcı faktör analizi sonucunda, belirlenen kritik $\mathrm{t}$ değerinden daha küçük $t$ değerine sahip olan üç maddenin kendi örtük değişkenini iyi temsil etmediği düşünülerek modelden çıkarılmış ve 12 madde için analizler, belirlenen 3 faktör dikkate alınarak yeniden gerçekleştirilmiştir. Doğrulayıcı faktör analizinde uyum iyiliği değerlerini iyileştirmek için aynı faktörler arasında yer alan 2. madde ile 3 . madde ve 2 . madde ile 4 . madde arasında kovaryans yapılmıştır. Kovaryans sonucu hesaplama tekrardan yapılmış ve uyum iyiliği değerleri tekrardan hesaplanmıştır $(\chi 2 / \mathrm{sd}=2,88 \mathrm{GFI}=0,92 \mathrm{AGFI}=0,90 \mathrm{CFI}=0,92 \mathrm{RMSA}=0,68 \mathrm{RMR}=0,010 \mathrm{NFI}=0,90)$. Sağlık arama davranış1 ölçeğinin bağlam geçerliliğini sağlamak için sağlıklı kaygısı ölçeği ile birlikte uygulanmış ve pozitif yönde anlamlı çıkmıştır $(\mathrm{p}<0,05)$. Korelasyon kat sayısı ise $\mathrm{r}=0.214$ 'dür.Taslak ölçeğin test-tekrar test puan ortalamaları arasındaki uyumluluğu gösteren Pearson momentler çarpımı korelasyon analizinde, iki ölçüm arasında istatistiksel olarak anlamlı, pozitif yönde bir ilişki bulunmuştur $(\mathrm{r}=0.200 ; \mathrm{p}=0.00)$. Taslak ölçeğin 4 ay ara ile tekrarlanan iki ölçüm sonucu ile elde edilen puanlar arasındaki fark bağımlı gruplarda t-testi analizi kullanılarak incelendi. İki uygulama arasındaki farkın istatistiksel olarak anlamlı olmadığı bulunmuştur $(\mathrm{t}=-0,074 ; \mathrm{p}=0.941)$.

\section{Sonuç ve Tartışma:}

Araştırma sonucunda yetişkinlerin sağlık arama davranışını gösteren 12 madde ve 3 faktörden oluşan bir ölçek geliştirilmiştir. Ölçek online arama, geleneksel arama ve profesyonel arama boyutlarından oluşmaktadır. Online arama 6 maddeden (Hastalığımla ilgili internetten araştırma yaparım, hastalığımla ilgili televizyondaki programları takip ederim, hastalığımla ilgili internetten hekimlerle iletişime geçerim, hastalandığımda kullandığım ilaçların yan etkilerine internetten bakarım, hastalığımla ilgili internetten formları takip ederim, hastalığımla ilgili online olarak dergi ve kitaplarda tarama yaparım), profesyonel arama 3 maddeden (Hastalandığımda hemen aile hekimine başvuru yaparım, hastalı̆̆ımla ilgili aile hekimimin yönlendirmesine dikkat ederim, hekimin tavsiye ettiği gidaları almaya dikkat ederim) ve geleneksel arama 3 maddeden (Evde bulunan bitkisel ilaçlarla iyileşmeye çalışırım, hastalığım için güvendiğim kişilerin tavsiyelerine dikkat ederim, daha önce aynı hastalı̆̆ geçirmiş kişilerin tavsiyelerine dikkat ederim) oluşmaktadır. 
Süleyman Demirel Üniversitesi Vizyoner Dergisi, Yıl: 2021, Cilt: 12, Sayı: 29, 224-234.

Süleyman Demirel University Visionary Journal, Year: 2021, Volume: 12, No: 29, 224-234.

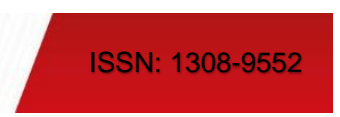

\section{INTRODUCTION}

People in almost every culture with serious complaints about their bodiessearch for various waysto resolve these complaints. This search sometimes results in applying to a physician, sometimes self-medication, sometimes adhering to the suggestion of a person they trust, and sometimes hoping for help from supernatural powers (Akman, 2015). The issue of what people do for their health and diseases, in other words, their health behavior is important because of their culture and individual characteristics. Nowadays, with the developing technology, people can search for health through online method.

In order to resolve their illness or discomfort, individuals may go to the medical treatment centers or to contact the doctor directly, called as proffessional method. Apart from this method, they may also consult hodjas, magicians, friends and herbal medicines, called as traditional method (Bahar, Savaş and Bahar, 2010; Özkorumak, Güleç, Kose, Borckardt and Sayar, 2006). The traditional method is knowledge, skills and practices based on theory, belief and experience specific to different cultures, used in health protection and prevention, diagnosis or treatment of mental illnesses (WHO, 2018). Traditional medicine is the method of treating illnesses at home by means of information derived from religious beliefs, values and other cultural elements, which are generally passed from generation to generation in rural areas (Oner, 2014). The reason why it is common in rural areas can be attributed to the fact that people of these areas prioritize traditional health beliefs and practices, they have negative attitudes towards modern medical methods and medical organizations, the structure of rural areas are conservative, education levelof people are low (Oner, 2014). Factors such as no need to make an appointment, the low cost of the service provided, the presence of the tools and equipment used by the patient or the practitioner are considered as the main factors for choosing traditional treatments (Güleç, Yenilmez and Ay, 2011). In the last century, a large proportion of the population in developing countries prefers the traditional method for primary care (WHO, 2018).

Another method that individuals will seek to cure the disease is the professional method. Individuals who want to resolve their discomfort may go to the nearest health facility and try to get treatment there. Belief, expectation and perceptions about the person's illness can be effective in choosing this method (Pennebaker, 1982). It is noteworthy that people with any complaints first consult trusted people such as spouses, friends and relatives, and a very small group consults directly to a health institution (Scambler and Scambler, 1984). Professional sector providing health servicesin the world is the sector where some occupations with ethical values who are accepted by official authorities and who have received a certain education in the field of health, such as physicians, nurses, pharmacists, dieticians and physiotherapists are included (Hayran and Sur, 1998). According to studies, even though threequarters of the population have a health-related complaints at any time, only one third of them consult the physician for help. The vast majority who do not get medical advice of the physician either tries traditional practices or takes self-medication. Sometimes they decidethemselves on the medicinethey will use, sometimes they follow the advice of their relatives, and sometimes they consult the pharmacist. Self-medication is common especially for symptoms such as headache, indigestion and fever (Yalmaz, 2011)

The Internet has changed the way people search for various information, entertainment and communication needs. It offers the opportunity of easy access, a wide range of pictorial and audiovisual health resources, and asking experts' views (Gallagher and Doherty, 2009). Internet usage for health information is becoming increasingly common (Rice, 2006). The Internet is an important resource for individuals seeking health information for a variety of purposes, including a new symptom or diagnosis, treatment options and information about medicine (Rice, 2006). Online methods in information search for health have been used too much. The literature shows that four out of ten adults and one out of four adolescents used the Internet to access health information in the previous year (Baker, Wagner, Singer and Bundorf, 2003). When daily search by topic on the Internet is considered on a global basis, it has been found that health-related topics are searchedat a rate of $4.5 \%$ (Bass et al., 2006). Developments in information technologies and easy access to online information have enabled all people, especiallythe patients to take an active role in managing their health. (Zülfikar, 2014). In order to make a decision about their health, people use information from the internet at a rate of $74 \%$ (Schwartz et al., 2006). This use may directly be for themselves or for relatives. In a study, it was emphasized that the information obtained from the Internet could be used more effectively in health decision-making process when discussed with health counselors (Broom, 2005). Searched health information contains advice and information on conditions, symptoms and treatment options (Shuyler and Knight, 2003). In addition to the informative potential of the Internet,it is clear that online communities are gathering around specific health problems and"chatting" about these health problems and treatment programs with experts in the medical field (Hardey, 1999; Sharf, 1997)). Advantages of using online 
health information include cost savings, privacy protection, obtaining information effectively and efficiently and adaptation of the information to meet the needs of a person (Cline and Haynes, 2001). Online search for health information can improve health care outcomes by reducing healthcare inequality and encouraging active interactions between patients anddoctors (Welch Cline et al., 2007).

Studies have shown that women are more likely to use the Internet as a source of health information than men (Baker et al., 2003; Ybarra and Suman, 2006). Middle-aged adults are more likely to search foronline information compared to their older and younger adult peers (HON, 1999).

When individuals do not feel well, they will have to seek a cure to overcome their discomfort. They will try to resolve this by taking professional health care servicesand using online or traditionalmethods. This study aims to develop a behavioral scale to determine the health search behavior of individuals.

\section{METHOD}

The research was applied to people aged 18 and over residing in Selcuklu district of Konya. The population of the study consists of 449.749 people, and 401 people were reached using the convenience sampling method. Studies are divided into three categories as instantaneous, cross-sectional and longitudinal according to the collection time of the data (Büyüköztürk, Kılıç Çakma, Akgün, Karadeniz and Demirel, 2013). Accordingly, the data required for the study were collected instantly by the researcher using the survey technique at a specified interval. The questionnaire first includes informed consent, then demographic data and scale. While evaluating the findings obtained in the study, SPSS (Statistical Package for Social Sciences) and LISREL program were used. 46.1\% of the participants are women and $53.9 \%$ are men. $80.8 \%$ of the participants do not have a chronic disease. In the development of the health seeking behavior scale, the content validity was first and then the construct validity. Findings on coverage and construct validity are given below. The study is prepared from the Thesis / Ph. D. dissertation of student Ramazan KIRAÇ titled "Factors Affecting the Health Seeking Behavior: A Study Based on Structural Equation Modeling " whose supervisor is Assoc. Prof. Yunus Emre ÖZTÜRK and that is supported defended on 14.11.2019. For the study, "Ethics Committee Approval" no 2018/122 dated 25.04.2018 is taken from the Ethics Committee of Selcuk University Faculty of Health Sciences.

\subsection{Scope Validity}

Scope validity study is conducted in order to determine the degree to which the items in a scale represent the defined behavior to be measured and to test the suitability of the scale for measurement purposes (Büyüköztürk, et al. 2013; Fraenkel, Wallen and Hyun, 2011). For the scope validity of the scale, the relevant literature was reviewed and the scale was composed of 30 items. The participants were expected to express their perceptions on a 5-point Likert-type scale ranging from "totally Agree" "Agree" "Partially Agree"“Disagree" and "Strongly disagree". For each item, "totally agree"was 5 points, "agree”was 4 points, "neutral” was 3 points, "disagree" was 2 points and "strongly disagree" was 1 point.

\subsection{Construct Validity}

Construct validity indicates "the degree to which an abstract concept can be accurately measured in the context of the desired behavior" ofa test (Büyüköztürk et al., 2013). Factor analysis (basic component analysis) was used to examine the construct validity of the scale (Tabachnick and Fidell, 2007). Prior to factor analysis, confirmatory factor analysis was applied to the explorer.

\section{Exploratory Factor Analysis}

Exploratory factor analysis was performed to determine the factor structure of the scale. Prior to factor analysis, the Kaiser-Meyer Olkin (KMO) and Barlett tests performed to determine the suitability of the data and sample for basic component analysis revealed that the Kaiser-Meyer Olkin (KMO) coefficient was 0.810 and the Barlett test was significant $(\mathrm{p}<0.001)$. The fact that KMO coefficient was higher than 0.60 and the Bartlett test was significant ( $\mathrm{p}<0.001)$ indicates that the data set is suitable for the principal component analysis, it can be factorized and sample size $(n=401)$ is sufficient (Büyüköztürk et al., 2013; Field, 2005). While analyzing the values obtained after the factor analysis, it wasnoticed that the scale items had a high load value in a single factor and the difference in load values in two or more factors was at least 0.1 and the load values in the factor they were included were 0.45 or higher (Büyüköztürk et al., 2013) Since the items with high load values on a multi-factor scale had to be 
subtracted from the scale, fourteen items with high load values (above 0.45) in two factors were subtracted from the scale (Bandalos and Finney, 2018). The remaining 16 items were analyzed again.

Table 1. Factor Analysis Results

\begin{tabular}{|c|c|c|c|c|c|c|c|c|c|}
\hline \multicolumn{10}{|c|}{ Total Variance Explained } \\
\hline \multirow{2}{*}{ Factor } & \multicolumn{3}{|c|}{ Initial Eigenvalues } & \multicolumn{3}{|c|}{ Extraction Sums of Squared Loadings } & \multicolumn{3}{|c|}{ Rotation Sums of Squared Loadings } \\
\hline & Total & $\%$ of Variance & Cumulative \% & Total & $\%$ of Variance & Cumulative \% & Total & $\%$ of Variance & Cumulative $\%$ \\
\hline 1 & 3,355 & 20,966 & 20,966 & 3,355 & 20,966 & 20,966 & 2,864 & 17,900 & 17,900 \\
\hline 2 & 2,563 & 16,016 & 36,982 & 2,563 & 16,016 & 36,982 & 2,440 & 17,628 & 33,151 \\
\hline 3 & 1,567 & 13,797 & 50,779 & 1,567 & 9,797 & 46,779 & 2,180 & 15,252 & 50,779 \\
\hline 4 & ,998 & 6,937 & 54,716 & & & & & & \\
\hline 5 & ,980 & 6,125 & 60,841 & & & & & & \\
\hline
\end{tabular}

As seen in Table 1, there are 3 factors whose eigenvalues are above 1.Values after rotation show that the scale has 3 factors. The total variance explained by three factors is $50.779 \%$.

Table 2. Varimax Values After Rotation

\begin{tabular}{|c|c|c|c|c|}
\hline Factor and Item & & & & Explained Variance \\
\hline Factor1: Online healt-seking behavior & Factor Value & & & \multirow{7}{*}{17,900} \\
\hline Item_1 & ,677 & & & \\
\hline Item_2 & ,628 & & & \\
\hline Item_3 & 670 & & & \\
\hline Item_4 & ,735 & & & \\
\hline Item_5 & ,765 & & & \\
\hline Item_13 & ,587 & & & \\
\hline Factor 2: Professionel healt-seking behavior & & Factor Value & & \multirow{7}{*}{17,628} \\
\hline Item_7 & & ,630 & & \\
\hline Item_8 & & ,586 & & \\
\hline Item_11 & & ,726 & & \\
\hline Item_12 & & ,706 & & \\
\hline Item_15 & &, 573 & & \\
\hline Factor 3: Traditional healt-seking behavior & & & Factor Value & \\
\hline Item_19 & & & 611 & \multirow{5}{*}{15,252} \\
\hline Item $\_21$ & & & ,799 & \\
\hline Item $\_22$ & & & ,686 & \\
\hline Item_27 & & & ,613 & \\
\hline Item _28 & & & 670 & \\
\hline
\end{tabular}

When Table 2 is examined, the factors under which the items are located, the factor load values of the variance and items explained by each factor are given. The fact that the item factor load value is above 0.40 and it does not take place in more than one factor with a load value of more than 0.40 was accepted as a criterion for the item to be considered qualified.

Expressions within the first factor are related to online health seeking behaviors. Therefore, the first factor is called online health search. The online health seeking factor consists of 6 items. The variance explained by this factor consisting of factor loadings ranging from 0.587 to 0.765 is 17.900 . 
The second factor is related to professional health search behavior. Therefore, the first factor is called isim professional health search. The professional health search factor consists of 5 items. The variance explained by this factor consisting of factor loadings ranging from 0.573 to 0.726 is 17,628 .

The third factor is related to traditional health-seeking behaviors. Therefore, the first factor is called traditional health search ".The traditional health search factor consists of 5 items. The variance explained by this factor consisting of items with factor loads ranging from 0.613 to 0.799 is 15,252 .

\section{Confirmatory factor analysis}

Although the main factors related to the scale of health search behavior were determined by exploratory factor analysis, information on the quality of the factors, the general structure of the scale and the extent to which the scale explained the health search behavior were determined by confirmatory factor analysis. Lisrel 8.80 package program was used to perform confirmatory factor analysis. Within the framework of the program, the DFA process took place in three stages. The process of creating, testing and evaluating the model has been worked out.

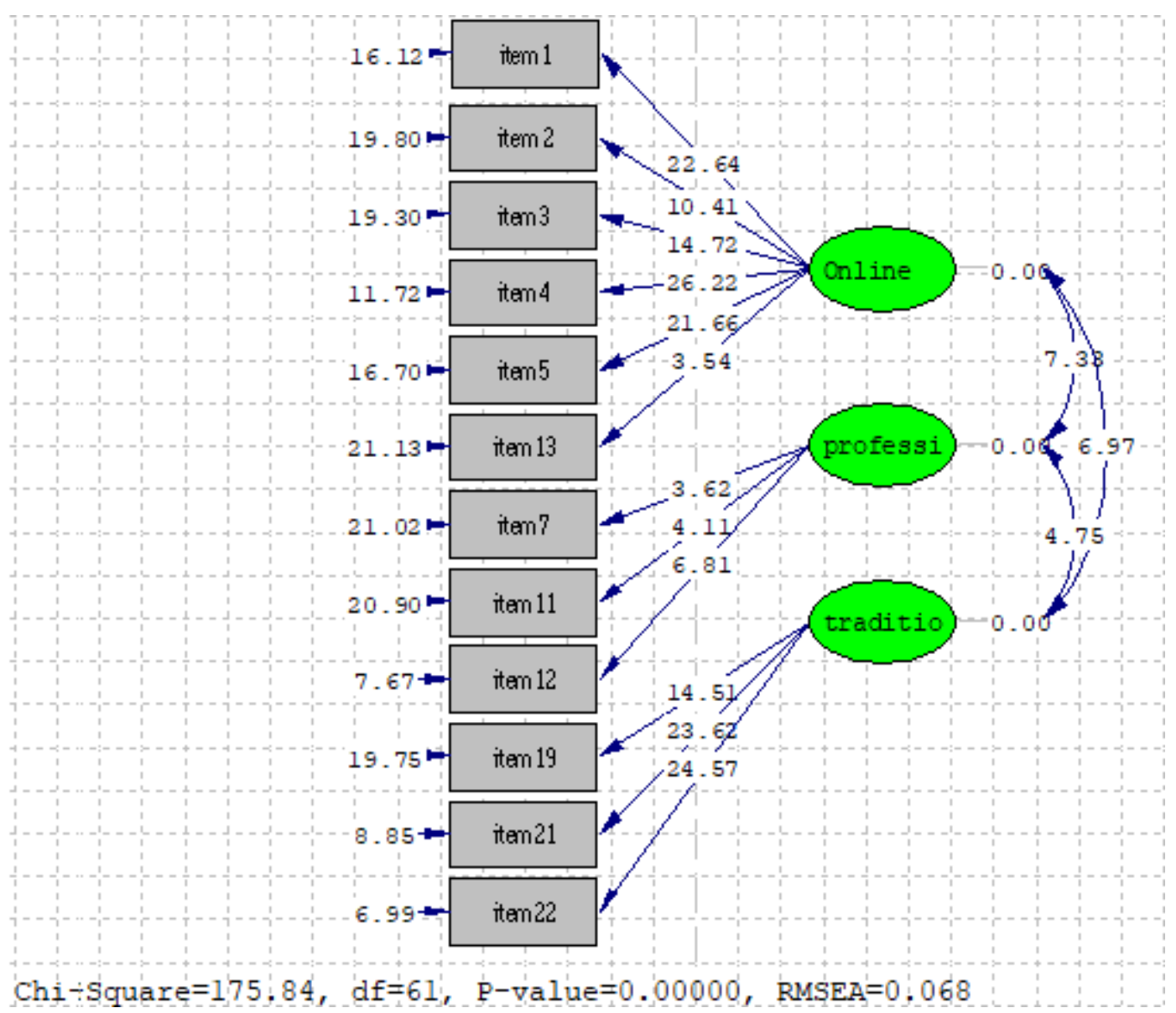

Figure 1. Confirmatory Factor Analysis t Values

$\mathrm{T}$ values of the scale items were givenin figure 3. According to the analyzes, it was observed that all items except the $8^{\text {th }}, 15^{\text {th }}, 27^{\text {th }}$ and $28^{\text {th }}$ items in the second and third factors (the observed variable) were significant at the level of representing their implicit variable at 0.05 . The $t$ values calculated for the four items mentioned were less than 1.96 , which was the critical value for the level of 0.05 . Therefore, these three items with a t value smaller than the critical $t$ value, were subtracted from the model considering that they did not represent their own implicit variable and the analyzes for 12 items were re-performed considering the 3 factorsdetermined.

As seen in figure 3. repeated analyzes after subtraction of relevant items showed that all of the items' (the observed variable) level of representing their own implicit variable was significant at 0.05 level. The t values calculated for 
a total of 12 items were greater than 1.96, which was the critical value determined for the level of 0.05 . This means that each item represents its implicit variable well and can therefore be included in the scale.

Table 3. Goodwill Values Used in CFA

\begin{tabular}{lccc}
\hline Index & Normal Value & Acceptable Value & Model Values \\
\hline$\chi 2 /$ sd & $<2$ & $<5$ & $175,84 / 61=2,88$ \\
GFI & $>0.95$ & $>0.90$ & 0,92 \\
AGFI & $>0.95$ & $>0.90$ & 0.90 \\
CFI & $>0.95$ & $>0.90$ & 0,92 \\
RMSEA & $<0.05$ & $<0.08$ & 0,068 \\
RMR & $<0.05$ & $<0.08$ & 0.010 \\
NFI & $>0.95$ & $>0.90$ & 0.90 \\
\hline
\end{tabular}

The normal value and acceptable values of the goodness of fit index values used in confirmatory factor analysis are givenin Table 3. In the table, goodness of fit index values are also given as a result of confirmatory factor analysis (Hooper, Coughlan and Mullen, 2008; Munro, 2005; Schreiber, Nora, Stage, Barlow and King, 2006; Şimşek, 2007; Wang and Wang, 2019; Toygar and Kırlığlu, 2020; Kıraç, 2019). In the confirmatory factor analysis, covariance was made between the $2^{\text {nd }}$ item and $3^{\text {rd }}$ item, and the $2^{\text {nd }}$ item and the $4^{\text {th }}$ item, which are among the same factors, to improve the goodness of fit values. As a result of covariance, the calculation was repeatedand the goodness of fit values were calculated again. The goodness of fit values of the health search behavior scale are as follows; $902 / \mathrm{sd}=2.88 \mathrm{GFI}=0.92 \mathrm{AGFI}=0.90 \mathrm{CFI}=0.92 \mathrm{RMSA}=0.68 \mathrm{RMR}=0.010$ $\mathrm{NFI}=0.90$.

\subsection{Context Validity}

In order to ensure context validity of the health search behavior scale, it was applied together with the scale of health anxiety and it was found to be positive $(\mathrm{p}<0.05)$. The correlation coefficient is $r=0.214$.

\subsection{Test-Retest Analysis}

Pearson product-moment correlationanalysis showing the compatibility between the test-retest mean scores of the draft scale showed that there was statistically positive correlation between two measurements $(r=0.200 ; p=0.00)$. The difference between the scores obtained with two measurement results repeated with an interval of 4 months of the draft scale was examined by using t-test analysis in the dependent groups. The difference between the two applications was not found to be statistically significant $(\mathrm{t}=-0,074 ; \mathrm{p}=0.941)$. The research was applied to 400 people as in the first sample. Of the participants, $61.3 \%$ were male, $38.7 \%$ were female and $75.8 \%$ had no chronic illness.

\subsection{Findings Related to the Reliability of the Scale}

Cronbach's alpha reliability coefficients, which give information about whether the items included in each factor within the scale measure the desired feature, are as follows.

Table 4. Factors and Alpha Reliability Coefficients for the Scale

\begin{tabular}{ccccc}
\hline & 1. Factor & 2. Factor & 3. Factor & The Scale \\
\hline Number of Items & 6 & 3 & 3 & 12 \\
Cronbach $\boldsymbol{\alpha}$ & 0.726 & 0.720 & 0.736 & 0.755 \\
\hline
\end{tabular}

As shown in Table 4, Cronbach's internal consistency reliability coefficient was 0.726 for the first factor; 0,720 for the second factor; 0.736 for the third factor; and 0,755 for the whole scale. 
Table 5. Correlation Analysis of Scale Factors.

\begin{tabular}{lcccc}
\hline & & Factor 1 & Factor 2 & Factor 3 \\
\hline \multirow{2}{*}{ Factor 1 } & $\mathrm{r}$ & 1 &, $216^{* *}$ &, $262^{* *}$ \\
& $\mathrm{p}$ & &, 000 &, 000 \\
\hline \multirow{2}{*}{ Factor 2 } & $\mathrm{r}$ &, $216^{* *}$ & 1 &, $132^{* *}$ \\
& $\mathrm{p}$ &, 000 & &, 003 \\
\hline \multirow{2}{*}{ Factor 3 } & $\mathrm{r}$ &, $262^{* *}$ &, $132^{* *}$ & 1 \\
& $\mathrm{p}$ &, 000 &, 003 & \\
\hline
\end{tabular}

As shown in Table 5, correlation analysis of the scale items was given. Correlation analysis shows that all factors are related to each other. Low levels of relationship indicate that scale items are included in the right factors.

\section{CONCLUSION}

As a result of the research, a scale consisting of 12 items and 3 factors showing the health seeking behavior of adults was developed. The scale consists of online search, traditional search and professional search dimensions. Online search consists of 6 items, 3 items of traditional search and 3 items of professional search. The final form of the substances belonging to the research scale is as follows.

\section{Factor 1: Online health search}

1. I do research on the internet about my disease.

2. I follow programs about my illness on television

3. I contact the doctors on the internet about my disease.

4. I look at the side effects of the drugs I use on the Internet when I get sick.

5. I follow the forms about my illness on the Internet.

6. I scan in journals and books about my disease.

\section{Factor 2: Professional health search}

7. When I am ill, I apply to the physician immediately.

8. I pay attention to the advise of physician about my disease

9.I try to take the food recommended by the doctor

\section{Factor 3: Search for traditional health}

10. I try to heal with herbal drugs at home.

11. I pay attention to the advice of people I trust for my illness.

12. I pay attention to the advice of people who have had the same disease before.

As a result of the explanatory and confirmatory factors, a total of 18 items were excluded from the scale. Items extracted from the health seeking behavior scale are given below.

1. When I get sick, I do not take medication even if I think I will recover without consulting a doctor.

2. When I get sick, I immediately apply to the emergency.

3. First of all, I prefer the nearby hospital.

4. I pay attention that the health institution has a quality certificate.

5. I did contact the health care provider can get the cheapest health services.

6. I go to the hospital even if there are intimate matters 
7. I do not act on the decision of a hospital about my illness.

8. I take care to buy herbal medicine from herbalists for my health.

9. I consider going to the hot springs for my illness.

10. When I get sick, I wait thinking that it will pass by prayer

11. When I get sick, I do not intervene, thinking that it will pass by itself.

13. Advertising and promotions about my illness attract and direct my interest.

14. I seek solutions for intimate issues on the internet

15. When I get sick, I use the drugs recommended by the close environment.

16. When I get sick, I use home remedies.

17. I get information about my illness from healthcare friends.

18. I take care to do sports related to my illness

\section{DECLARATION OF THE AUTHORS}

Declaration of Contribution Rate: The first author contributes $60 \%$ while the second author contributes $40 \%$.

Declaration of Support and Thanksgiving: Thank you to the individuals who participated in the surveys.

Declaration of Conflict: There is no potential conflict of interest in this study.

\section{REFERENCES}

Akman, M. (2015). Sağlık arama davranışı Türk Aile Hekim Dergisi, 19(2), 53-54. doi:10.15511/tahd.15.02053

Bahar, A., Savaş, H. A. and Bahar, G. (2010). Psikiyatri hastalarında tıp dışı yardım arama davranışının değerlendirilmesi. New Symposium Journal, 48(3), 216-222.

Baker, L., Wagner, T. H., Singer, S. and Bundorf, M. K. (2003). Use of the Internet and e-mail for health care information: results from a national survey. JAMA, 289(18), 2400-2406. doi:10.1001/jama.289.18.2400

Bandalos, D. L. and Finney, S. J. (2018). Factor analysis: Exploratory and confirmatory. The reviewer's guide to quantitative methods in the social sciences in (98-122), Routledge.

Bass, S. B., Ruzek, S. B., Gordon, T. F., Fleisher, L., McKeown-Conn, N. and Moore, D. (2006). Relationship of Internet health information use with patient behavior and self-efficacy: experiences of newly diagnosed cancer patients who contact the National Cancer Institute's Cancer Information Service. J Health Commun, 11(2), 219-236. doi:10.1080/10810730500526794

Broom, A. (2005). Virtually he@lthy: the impact of internet use on disease experience and the doctor-patient relationship. Qualitative Health Research, 15(3), 325-345. doi:10.1177/1049732304272916

Büyüköztürk, Ş., Kılıç Çakma, E., Akgün, Ö., Karadeniz, Ş. and Demirel, F. (2013). Bilimsel Araştırma Yöntemleri. Pegem Akademi.

Cline, R. J. and Haynes, K. M. (2001). Consumer health information seeking on the Internet: the state of the art. Health Educ Res, 16(6), 671-692. doi:10.1093/her/16.6.671

Field, A. (2005). Discovering statistics using SPSS (2005) London: Sage Publications.

Fraenkel, J. R., Wallen, N. E. and Hyun, H. H. (2011). How to design and evaluate research in education: New York: McGraw-Hill Humanities/Social Sciences/Languages.

Gallagher, S. and Doherty, D. T. (2009). Searching for health information online: characteristics of online health seekers. J Evid Based Med, 2(2), 99-106. doi:10.1111/j.1756-5391.2009.01021.x 
Süleyman Demirel Üniversitesi Vizyoner Dergisi, Yıl: 2021, Cilt: 12, Sayı: 29, 224-234.

Süleyman Demirel University Visionary Journal, Year: 2021, Volume: 12, No: 29, 224-234.

Güleç, G., Yenilmez, Ç. and Ay, F. (2011). Bir Anadolu şehrinde psikiyatri kliniğine başvuran hastaların hastalık açıllama ve çare arama davranışları. Klinik Psikiyatri Dergisí, 14(3), 131-142.

Hardey, M. (1999). Doctor in the house: the Internet as a source of lay health knowledge and the challenge to expertise. Sociology of Health, 21(6), 820-835. doi:10.1111/1467-9566.00185

Hayran, O. and Sur, H. (1998). Sağllk Hizmetleri El Kitabl: Nobel Kitapevleri.

HON. (1999). Health on the Net Foundation, HON's fourth survey on the use of the Internet for medical and health purposes, Access address: www.hon.ch/Survey/ResumeApr99.html.

Hooper, D., Coughlan, J. and Mullen, M. R. (2008). Structural equation modelling: Guidelines for determining model fit. Electronic journal of business research methods, 6(1), 53-60.

Kıraç, R . (2019). Nomofobinin dikkat eksikliğine etkisi. OPUS Uluslararası Toplum Araştırmaları Dergisi, 14(20), 1095-1114

Munro, B. H. (2005). Statistical methods for health care research (Vol. 1): Lippincott williams \& wilkins.

Oner, C. (2014). Social determinants of health and quality of life relationship. Turkiye Klinikleri Journal of Family Medicine Special Topics, 5(3), 15-18.

Özkorumak, E., Güleç, H., Kose, S., Borckardt, J. and Sayar, K. (2006). Depresyon hastalarında tıp dışı yardım arama davranışı: Aleksitimi bir etken olabilir mi. Klinik Psikiyatri Dergisi, 9(4), 161-169.

Pennebaker, J. W. (1982). The Psychology of Physical Symptoms: Springer-Verlag New York.

Rice, R. E. (2006). Influences, usage, and outcomes of Internet health information searching: multivariate results from the Pew surveys. Int J Med Inform, 75(1), 8-28. doi:10.1016/j.ijmedinf.2005.07.032

Scambler, G. and Scambler, A. (1984). The illness iceberg and aspects of consulting behaviour. J. H. R. Fitzpatrick, S. Newman, G. Scambler and J. Thompson (Ed.), The Experience of Illness, London:Tavistock Publications.

Schreiber, J. B., Nora, A., Stage, F. K., Barlow, E. A. and King, J. (2006). Reporting Structural Equation Modeling and Confirmatory Factor Analysis Results: A Review. The Journal of Educational Research, 99(6), 323338. doi:10.3200/JOER.99.6.323-338

Schwartz, K. L., Roe, T., Northrup, J., Meza, J., Seifeldin, R. and Neale, A. V. (2006). Family medicine patients' use of the Internet for health information: a MetroNet study. J Am Board Fam Med, 19(1), 39-45. doi:10.3122/jabfm.19.1.39

Sharf, B. F. (1997). Communicating breast cancer on-line: support and empowerment on the Internet. Women Health, 26(1), 65-84. doi:10.1300/J013v26n01_05

Shuyler, K. S. and Knight, K. M. (2003). What are patients seeking when they turn to the Internet? Qualitative content analysis of questions asked by visitors to an orthopaedics Web site. Journal of medical Internet research, 5(4), e24-e24. doi:10.2196/jmir.5.4.e24

Şimşek, Ö. F. (2007). Yapısal eşitlik modellemesine giriş:(temel ilkeler ve LISREL uygulamalarl). Ekinoks.

Tabachnick, B. G. and Fidell, L. S. (2007). Multivariate regression. Using Multivariate Statistics . Boston, MA: Pearson Education, 117-159.

Toygar, Ş. A. Kırlığlu, M. (2020). Doğrulayıcı faktör analizi ile mesleki doyum ölçeği'nin yapı geçerliliğin sağlık ve sosyal hizmet çalışanları örnekleminde incelenmesi. Ankara Hacı Bayram Veli Üniversitesi İktisadi ve İdari Bilimler Fakültesi Dergisi, 22(1), 120-133.

Wang, J. and Wang, X. (2019). Structural equation modeling: Applications using Mplus: John Wiley \& Sons.

Welch Cline, R. J., Penner, L. A., Harper, F. W. K., Foster, T. S., Ruckdeschel, J. C. and Albrecht, T. L. (2007). The roles of patients' internet use for cancer information and socioeconomic status in oncologist-patient communication. Journal of oncology practice, 3(3), 167-171. doi:10.1200/JOP.0737001 
Süleyman Demirel Üniversitesi Vizyoner Dergisi, Yıl: 2021, Cilt: 12, Sayı: 29, 224-234.

Süleyman Demirel University Visionary Journal, Year: 2021, Volume: 12, No: 29, 224-234.

WHO. (2018). World Health Organization. Access address: https://www.who.int/.

Yalmaz, Ş. (2011). Tunceli ili Ovacık ilçesinde yaşayan kişilerin sağlık hizmetlerinden yararlanma ve memnuniyet düzeyinin ölçülmesi. Yüksek Lisans Tezi, Okan Üniversitesi Sosyal Bilimler Enstitüsü, İstanbul.

Ybarra, M. L. and Suman, M. (2006). Help seeking behavior and the Internet: a national survey. Int J Med Inform, 75(1), 29-41. doi:10.1016/j.ijmedinf.2005.07.029

Zülfikar, H. (2014). Hastaların İnternet kullanımı ve elektronik ortamdaki sağlık bilgilerine erişim davranışları. Florence Nightingale Hemşirelik Dergisi, 22(1), 46-52. 